\title{
WNT5A wt Allele
}

National Cancer Institute

\section{Source}

National Cancer Institute. WNT5A wt Allele. NCI Thesaurus. Code C53003.

Human WNT 5A wild-type allele is located within 3p21-p14 and is approximately $22 \mathrm{~kb}$ in length. This allele, which encodes protein wnt-5a, is involved in the mediation of fetal bilateral patterning. 